\title{
Mycobacterium brumae sp. nov., a Rapidly Growing, Nonphotochromogenic Mycobacterium
}

\author{
M. LUQUIN, ${ }^{1,2 *}$ V. AUSINA, ${ }^{1,2}$ V. VINCENT-LÉVY-FRÉBAULT, ${ }^{3}$ M. A. LANÉELLE, ${ }^{4}$ F. BELDA, ${ }^{1,2}$ \\ M. GARCÍA-BARCELÓ, ${ }^{1,2}$ G. PRATS, ${ }^{1}$ AND M. DAFFÉ ${ }^{4}$
}

Servicio de Microbiología, Hospital de la Santa Cruz y San Pablo, Departamento de Genética y Microbiología, Universidad Autónoma de Barcelona, 08025 Barcelona, ${ }^{1}$ and Servicio de Microbiologia, Hospital Germans Trias i Pujol, Departamento de Genética y Microbiología, Universidad Autónoma de Barcelona, 08915 Badalona, ${ }^{2}$ Spain, and Unité de la Tuberculose et des Mycobactéries, Institut Pasteur, 75724 Paris Cedex $15,^{3}$ and Departement III du LPTF du Centre National de la Recherche Scientifique et Université Paul Sabatier, 31062 Toulouse Cedex, ${ }^{4}$ France

\begin{abstract}
Strains of a new species of rapidly growing, nonphotochromogenic mycobacteria, Mycobacterium brumae, have been isolated from water, soil, and human sputum samples in Barcelona, Spain. The inclusion of this organism in the genus Mycobacterium is based on its acid-alcohol fastness, its DNA G+C content, its mycolate pattern, and its mycolate pyrolysis esters. A study of 11 strains showed that they form a homogeneous group with an internal phenotypic similarity value of $94.9 \pm 3.79 \%$. The results of a comparison with 39 other mycobacterial species and subspecies are also presented. DNA relatedness studies showed that the $M$. brumae strains studied form a single DNA hybridization group which is less than $30 \%$ related to 15 other species of the genus Mycobacterium. Thin-layer chromatographic analysis showed that only $\alpha$-mycolates are present. Unlike Mycobacterium fallax and Mycobacterium triviale $\alpha$-mycolates, $M$. brumae $\alpha$-mycolates release only 22 -carbon atom esters after pyrolysis. Strain CR-270 is the type strain; a culture of this strain has been deposited in the Collection Nationale de Cultures de Microorganismes de l'Institut Pasteur, Paris, France, as strain CIP 103465.
\end{abstract}

From 1983 to 1987 , in the course of a search for mycobacteria in environmental samples, we isolated 10 strains with homogeneous properties belonging to the genus Mycobacterium. Later, in 1991, a similar strain was isolated from a human sputum sample. These organisms were rapidly growing, nonphotochromogenic mycobacteria that differed from all known species and are considered members of a new species. These strains had a colonial morphology similar to that of Mycobacterium fallax and the same pattern of mycolates (only $\alpha$-mycolates) as determined by thin-layer chromatography (TLC) (16). Mycobacterium triviale is the only slowly growing Mycobacterium species with this pattern of mycolates $(4,16)$. Mycolic acids are useful taxonomic markers for the differentiation of mycobacteria at both the genus level and the species level. Mycobacterial mycolic acids are characteristically 2-branched, 3-hydroxy fatty acids with very long chains (up to 90 carbon atoms long) which are major lipid constituents in the cell wall $(4,7)$. By TLC they may be separated into seven types according to the content and position of different functional groups in their carbon chains $(18,19)$. Mycolic acid methyl esters release by pyrolysis straight esters with carbon chain lengths ranging from $\mathrm{C}_{22}$ to $\mathrm{C}_{26}(4,12,17)$. Within the genus Mycobacterium, variation in the pyrolysis ester chain lengths is an additional differential characteristic that is especially useful for subdividing groups of species that produce the same TLC pattern. The strains of the new species could be clearly distinguished from $M$. fallax and $M$. triviale by the chain lengths of their pyrolysis esters. Esters containing 22 and 24 carbon atoms were released by $\alpha$-mycolates of $M$. fallax, and tetracosanoate was the only ester liberated by $M$. triviale $\alpha$-mycolates $(14,16,17,22)$. In contrast, the $\alpha$-mycolates of the

\footnotetext{
* Corresponding author.
}

new strains give only docosanoate when they are subjected to pyrolytical cleavage. A subsequent structural analysis showed that there are great differences in the compositions of the $\alpha$-mycolates of these strains and the $\alpha$-mycolates of $M$. fallax and $M$. triviale. Genotypically, there was clear evidence for differentiation of these organisms, since the levels of DNA-DNA hybridization between the strains of the new taxon and other related species were less than $30 \%$. In this paper, we describe the characteristics of these strains and designate a new species, Mycobacterium brumae.

\section{MATERIALS AND METHODS}

Bacterial strains. A total of 11 strains were studied. Eight of these (strains CR-103, CR-104, CR-142, CR-210, CR-267, CR-268, CR $-270^{\mathrm{T}}$ [T = type strain], and CR-271) were isolated from water samples taken from the Llobregat River in Barcelona, Spain; two strains (strains CR-130 and CR-269) were isolated from soil; and one strain (strain CR-148) was isolated from a human sputum sample. In addition to these 11 isolates, we studied the following strains of species which are on the Approved Lists of Bacterial Names (24) or in the Index of the Bacterial and Yeast Nomenclatural Changes (20): Mycobacterium agri ATCC $27406^{\mathrm{T}}$; Mycobacterium aichiense ATCC $27280^{\mathrm{T}}$; Mycobacterium aurum ATCC $23366^{\mathrm{T}}$; Mycobacterium austroafricanum ATCC $33464^{\mathrm{T}}$; Mycobacterium chelonae subsp. chelonae NCTC $946^{\mathrm{T}}$ and CIPT 801159; Mycobacterium chelonae subsp. abscessus ATCC $19977^{\mathrm{T}}$; Mycobacterium chitae ATCC $19627^{\mathrm{T}} ;$ Mycobacterium chubuense ATCC $27278^{\mathrm{T}}$; Mycobacterium diernhoferi ATCC $19340^{\mathrm{T}}$; Mycobacterium duvalii NCTC $358^{\mathrm{T}}$; Mycobacterium fallax CIP $8139^{\mathrm{T}}$, CIPT 1390007, and CIPT 1390014; Mycobacterium flavescens ATCC $14474^{\mathrm{T}}$; Mycobacterium fortuitum ATCC $6841^{\mathrm{T}}$ and ATCC 14467; Mycobacterium gadium ATCC $27726^{\mathrm{T}}$; Mycobacterium gastri 
ATCC $15754^{\mathrm{T}} ;$ Mycobacterium gilvum NCTC $10742^{\mathrm{T}} ;$ Mycobacterium gordonae ATCC $14470^{\mathrm{T}}$ and CIPT 0210008; Mycobacterium kansasii ATCC $12478^{\mathrm{T}}$; Mycobacterium komossense ATCC $33013^{\mathrm{T}}$; Mycobacterium marinum ATCC 927 ${ }^{\mathrm{T}}$; Mycobacterium moriokaense ATCC 43059 ${ }^{\mathrm{T}}$; Mycobacterium neoaurum ATCC 25795 ${ }^{\mathrm{T}}$; Mycobacterium obuense ATCC $27023^{\mathrm{T}}$; Mycobacterium parafortuitum ATCC $19686^{\mathrm{T}}$; Mycobacterium phlei ATCC $11758^{\mathrm{T}}$; Mycobacterium porcinum ATCC $33776^{\mathrm{T}}$; Mycobacterium poriferae ATCC $35087^{\mathrm{T}}$; Mycobacterium pulveris ATCC $35154^{\mathrm{T}}$; Mycobacterium rhodesiae ATCC $27024^{\mathrm{T}}$; Mycobacterium senegalense NCTC $10956^{\mathrm{T}}$; Mycobacterium smegmatis ATCC $19420^{\mathrm{T}}$; Mycobacterium sphagni ATCC $33027^{\mathrm{T}}$; Mycobacterium terrae ATCC $15755^{\mathrm{T}}$; Mycobacterium thermoresistibile ATCC $19527^{\mathrm{T}} ;$ Mycobacterium tokaiense ATCC $27282^{\mathrm{T}}$; Mycobacterium triviale ATCC 23292 ${ }^{\mathrm{T}}$; Mycobacterium tuberculosis ATCC $27294^{\mathrm{T}}$ and ATCC 25177; and Mycobacterium vaccae ATCC $15483^{\mathrm{T}}$. In addition, the frequency distribution of the test results and the results of a lipid analysis for mycobacterial isolates obtained from human host and environmental sources were included for comparative purposes. These isolates included $13 \mathrm{M}$. chelonae subsp. chelonae strains, $6 \mathrm{M}$. chelonae subsp. abscessus strains, $8 \mathrm{M}$. fallax strains, $7 \mathrm{M}$. flavescens strains, $12 \mathrm{M}$. fortuitum strains, $9 \mathrm{M}$. gastri strains, $28 \mathrm{M}$. gordonae strains, $21 \mathrm{M}$. kansasii strains, $4 \mathrm{M}$. marinum strains, $7 \mathrm{M}$. smegmatis strains, $13 \mathrm{M}$. terrae strains, $11 \mathrm{M}$. triviale strains, and $47 \mathrm{M}$. tuberculosis strains. We also included in this study six strains of a recently described new species, Mycobacterium alvei (1).

Characterization of strains. Colony morphology, the ability to grow at various temperatures $\left(25,30,37,45\right.$, and $\left.52^{\circ} \mathrm{C}\right)$, pigment production, and photoreactivity were determined as previously described $(9,10,28-30)$. The niacin test was performed with test strips (Difco Laboratories, Detroit, Mich.). Strains were tested for iron uptake by using a modification of the procedure of Szabo and Vandra (26), as described by Silcox et al. (23). The catalase test was performed by the method of Kubica and Pool (11). The nitrate reductase and arylsulfatase tests were performed as described by Vestal (28). The $\beta$-glucosidase, urease, penicillinase, and trehalase tests were performed as recommended by David and Jahan (5) and David et al. (6). Tests for resistance to hydroxylamine and sodium chloride, hydrolysis of Tween 80 , and $\beta$-galactosidase were performed as described by Wayne et al. $(29,30)$. Tests to determine the use of glucose, inositol, mannitol, and sodium citrate as sole carbon sources in the presence of ammoniacal nitrogen were performed by using the procedure of Silcox et al. (23). Tests to determine degradation of salicylate, tolerance to picric acid, and acid formation from carbon sources were performed as described by Tsukamura (27). Growth in the presence of different antibiotics was determined by using the method of Canetti et al. (2).

Lipid analysis. To isolate lipid components, all of the strains were cultivated on plates containing Middlebrook $7 \mathrm{H} 10$ agar and incubated at 30 or $37^{\circ} \mathrm{C}$ in the presence of $5 \%$ $\mathrm{CO}_{2}$. Fatty acid esters were prepared as previously described (4). Mycolates were obtained by precipitating them twice with methanol from the methyl ester mixture. We then checked by TLC that the pellet contained only mycolates. The mycolates were fractionated by argentation chromatography by using increasing proportions of diethyl ether in petroleum ether (22). This separation was followed by TLC on silver nitrate-impregnated commercial plates developed with petroleum ether-diethyl ether $(6: 4, \mathrm{vol} / \mathrm{vol})$. The spots were visualized by charring after the plates were sprayed with a $10 \%$ solution of molybdophosphoric acid in ethanol. Oxidative cleavage, isolation of oxidation products, and structural analysis were performed as previously described (13). The patterns of nonhydroxylated fatty acids were determined by capillary gas chromatography as previously described (17).

Instrumentation. Gas chromatography was conducted with a Hewlett-Packard model 5890A apparatus equipped with a fused silica capillary column with SPB1 as the stationary phase. The temperature of the injector was raised from 260 to $350^{\circ} \mathrm{C}$ for pyrolytical conditions. Infrared spectra were recorded with a Perkin-Elmer model FTIR 1600 apparatus. ${ }^{1} \mathrm{H}$ nuclear magnetic resonance spectra were obtained with a $200-\mathrm{MHz}$ Brucker instrument by using $\mathrm{CDCl}_{3}$ as the solvent. Polarimetry was conducted with a Perkin-Elmer model 141 polarimeter. Mass spectra were determined by using an electron impact ion source and a Varian model $311 \mathrm{~A}$ spectrometer.

DNA-DNA hybridization. For DNA extraction and subsequent DNA-DNA hybridization, selected strains (see Table 4) were cultivated in 1 to 3 liters of nutrient broth (Difco) supplemented with a powder base containing $7 \mathrm{H} 9$ Middlebrook broth medium (Difco), $1 \%$ glycerol, and $0.05 \%$ Tween 80 . Flasks were incubated at 30 or $37^{\circ} \mathrm{C}$ with gentle agitation for 10 to 21 days. DNA was extracted as previously described $(14,15)$. Briefly, the bacteria were converted to wall-deficient forms and then lysed by adding sodium dodecyl sulfate, as previously described, and proteinase $\mathrm{K}$ (Boehringer, Mannheim, Germany) instead of pronase. The DNA was then purified by using the usual methods. DNA from the type strain of the proposed new mycobacterial taxon, strain CIP 103465, was labeled in vitro by nick translation (nucleotides were obtained from the Radiochemical Centre, Amersham, England) as previously described (8), except that we modified the concentrations of some of the reagents, as follows: $3 \mu \mathrm{l}$ of DNA $(800 \mu \mathrm{g} / \mathrm{ml}), 40 \mu \mathrm{l}$ of S1 nuclease $(1$ $\mathrm{U} / \mathrm{ml}$; Sigma Chemical Co., St. Louis, Mo), and $15 \mu \mathrm{l}$ of DNase I $\left(10^{-8} \mathrm{~g} / \mathrm{ml}\right)$. Unlabeled DNAs were sheared by sonication in order to get DNA fragments that were 500 to $800 \mathrm{bp}$ long. The molecular weight of the sonicated DNA was checked by gel electrophoresis by using phage lambda hydrolyzed by restriction enzyme HindIII. The S1 nuclease method (3) in which the S1 nuclease-trichloroacetic acid procedure (8) was used was modified as previously described (14). The temperature $\left(T_{m}\right)$ at which $50 \%$ of the DNA became hydrolyzable by $\mathrm{S} 1$ nuclease was determined by using the procedure developed by Crosa et al. in 1973 (3) and modified as described previously $(14,15)$.

Numerical taxonomy analysis. The data obtained from our study of 59 taxonomic properties were recorded as positive or negative, and the matching coefficient ( $M$ value) was calculated by using the following equation: $M$ value $=(\mathrm{ns} \times$ $100) /(n s+n d)$, where ns is the number of characters for which two strains gave the same results (both positive or both negative) and nd is the number of characters for which the strains gave different results (one positive and one negative) (25). The computer which we used was an IBM model 3083/XE/VM/SP-HPC computer. The program which we used is included in the Clustan 2 packet of programs (Computing Laboratory, University of St. Andrews, St. Andrews, Scotland). 

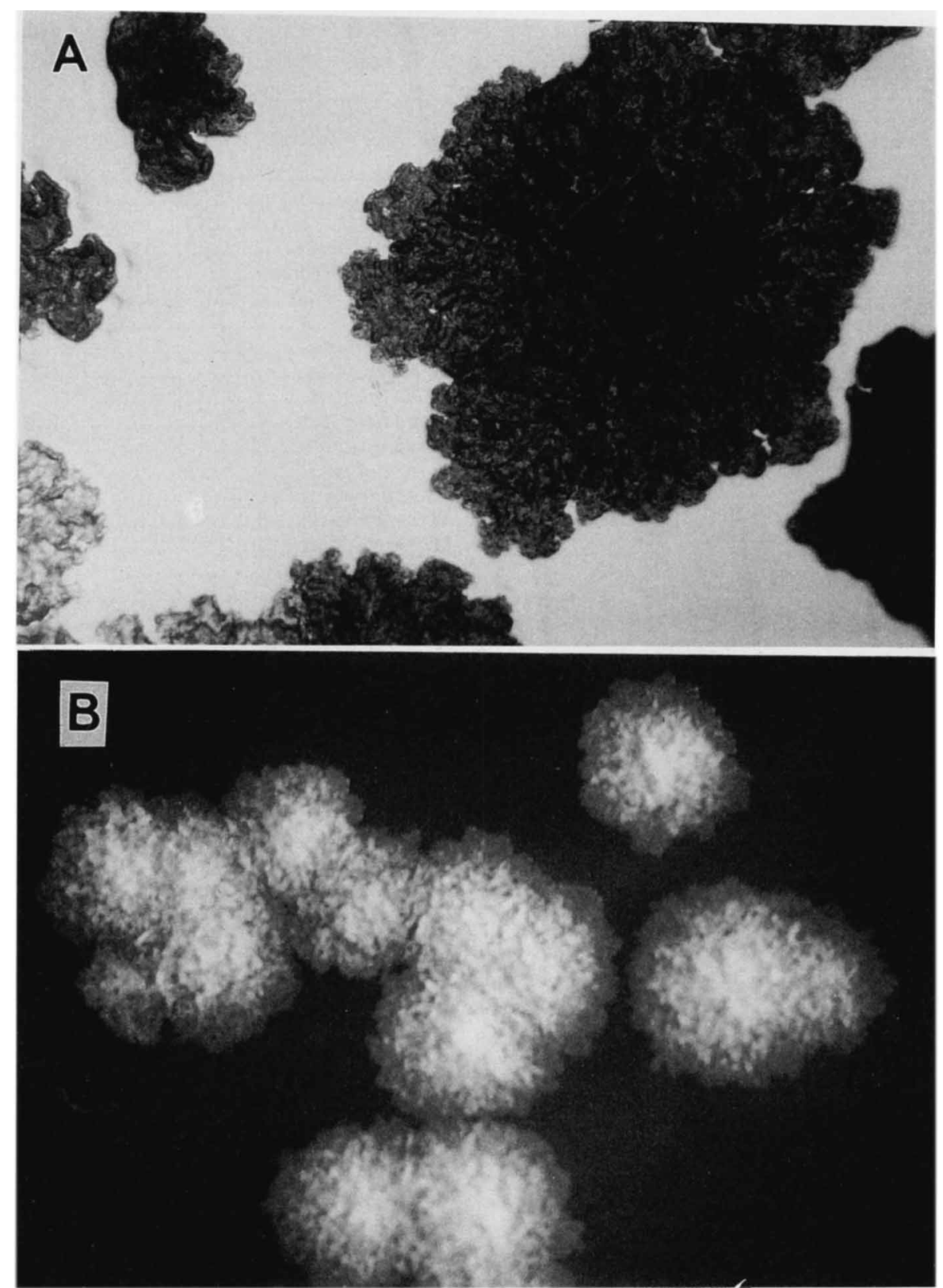

FIG. 1. Mature $M$. brumae CIP $103465^{\mathrm{T}}$ colonies on Middlebrook $7 \mathrm{H} 10$ medium. (A) Micrograph. Magnification, $\times 120$. (B) No magnification.

\section{RESULTS AND DISCUSSION}

Cells of the 11 new strains grown on Löwenstein-Jensen agar and on Middlebrook 7H10 agar were rod shaped, gram positive, and acid-alcohol fast and were able to form clumps and cords. Spores, capsules, and true branching were not observed. At 25,30 , and $37^{\circ} \mathrm{C}$, growth occurred within 4 to 5 days on Löwenstein-Jensen and Middlebrook 7 H10 media and on nutrient agar. Dilute inocula on Middlebrook agar yielded large, eugonic, buff-colored, rough colonies (Fig. 1). The phenotypic properties of the $11 \mathrm{M}$. brumae strains are shown in Table 1 . These strains constituted a homogeneous group with a level of internal similarity of $94.9 \pm 3.79 \%$. Comparisons of $M$. brumae CIP $103465^{\mathrm{T}}$ with the type strains of 39 other mycobacterial species revealed degrees of similarity of $80 \%$ with $M$. alvei, $75.8 \%$ with $M$. fallax, and
$75 \%$ with $M$. moriokaense (Table 2). Characteristics which differentiate $M$. brumae from phenotypically related $\mathbf{M y c o}$ bacterium species are shown in Table 3 .

Lipid analysis. Gas chromatographic analysis revealed the presence of hexadecanoate, octadecenoate, and tuberculostearate (10-methyloctadecanoate) as the major fatty acid methyl esters in lipid extracts of the $11 \mathrm{M}$. brumae strains (Fig. 2). All $M$. brumae strains exhibited a TLC pattern consisting of only one spot corresponding to $\alpha$-mycolate (Fig. 3). When pyrolytical conditions were used, the gas chromatographic profile showed an increase of methyl docosanoate $\left(\mathrm{C}_{22}\right)$, whereas $M$. fallax mycolates liberated by pyrolysis do- and tetracosanoate $\left(\mathrm{C}_{22}\right.$ and $\left.\mathrm{C}_{24}\right)$ and $M$. triviale liberated only tetracosanoate $(4,16,17,22)$ (Fig. 2). The infrared spectrum of the purified mycolates from $M$. 
TABLE 1. Properties of the $M$. brumae type strain and 10 additional strains

\begin{tabular}{|c|c|c|}
\hline Characteristic & Type strain ${ }^{a}$ & $\begin{array}{l}\text { Ten other } \\
\text { strains }^{b}\end{array}$ \\
\hline \multicolumn{3}{|l|}{ Morphology } \\
\hline Rods $(>1 \mu \mathrm{m}$ long $)$ & + & 100 \\
\hline Coccobacillary $(<1 \mu \mathrm{m}$ long $)$ & - & 0 \\
\hline Cord formation & + & 100 \\
\hline Smooth colonies & - & 0 \\
\hline Rough colonies & + & 100 \\
\hline Pigmentation in the dark & - & 0 \\
\hline Pigmentation in the light & - & 0 \\
\hline \multicolumn{3}{|l|}{ Growth at: } \\
\hline $25^{\circ} \mathrm{C}$ & + & 100 \\
\hline $30^{\circ} \mathrm{C}$ & + & 100 \\
\hline $30^{\circ} \mathrm{C}$ in $<5$ days & + & 100 \\
\hline $37^{\circ} \mathrm{C}$ & + & 100 \\
\hline $37^{\circ} \mathrm{C}$ in $<5$ days & + & 100 \\
\hline $45^{\circ} \mathrm{C}$ & - & 0 \\
\hline $52^{\circ} \mathrm{C}$ & - & 0 \\
\hline \multicolumn{3}{|l|}{ Growth on nutrient agar at: } \\
\hline $30^{\circ} \mathrm{C}$ & + & 100 \\
\hline $37^{\circ} \mathrm{C}$ & + & 100 \\
\hline $\begin{array}{l}\text { Growth on MacConkey agar without } \\
\text { crystal violet }\end{array}$ & - & 0 \\
\hline Iron uptake & + & 80 \\
\hline Niacin & - & 0 \\
\hline \multicolumn{3}{|l|}{ Enzymatic activities } \\
\hline Arylsulfatase ( 3 days) & - & 0 \\
\hline Catalase $\left(22^{\circ} \mathrm{C}\right)$ & + & 100 \\
\hline Catalase $\left(68^{\circ} \mathrm{C}\right)$ & $+w$ & $100^{c}$ \\
\hline$\beta$-Glucosidase $(3 \mathrm{~h})$ & + & 100 \\
\hline$\beta$-Galactosidase $(18 \mathrm{~h})$ & - & 0 \\
\hline Nitrate reductase $(2 \mathrm{~h})$ & + & 100 \\
\hline Penicillinase $(5 \mathrm{~h})$ & + & 100 \\
\hline Trehalase $(5 \mathrm{~h})$ & + & 100 \\
\hline Urease $(18 \mathrm{~h})$ & + & 100 \\
\hline Tween hydrolysis ( 10 days) & + & 100 \\
\hline Salicylate degradation ( 7 days) & - & 0 \\
\hline \multicolumn{3}{|l|}{ Acid produced from: } \\
\hline Glucose & + & 100 \\
\hline L-Arabinose & - & 0 \\
\hline Dulcitol & - & 0 \\
\hline Fructose & + & 100 \\
\hline meso-Inositol & + & 100 \\
\hline Mannitol & - & 0 \\
\hline L-Rhamnose & - & 0 \\
\hline D-Xylose & - & 20 \\
\hline Trehalose & + & 100 \\
\hline \multicolumn{3}{|l|}{$\begin{array}{l}\text { Use of the following compounds as } \\
\text { sole carbon sources: }\end{array}$} \\
\hline Glucose & + & 100 \\
\hline meso-Inositol & + & 100 \\
\hline Mannitol & - & 0 \\
\hline Fructose & + & 100 \\
\hline Sodium citrate & + & 100 \\
\hline \multicolumn{3}{|l|}{ Growth in the presence of: } \\
\hline Picric acid $(0.2 \%)$ & + & 50 \\
\hline $\mathrm{NaCl}(5 \%)$ & - & 0 \\
\hline $\mathrm{NH}_{2} \mathrm{OH}$ (500 mg/liter) & - & 20 \\
\hline D-Cycloserine (30 mg/liter) & - & 40 \\
\hline Ethambutol $(2 \mathrm{mg} /$ liter $)$ & - & 0 \\
\hline Streptomycin (4 mg/liter) & + & 100 \\
\hline Kanamycin ( $20 \mathrm{mg} / \mathrm{liter})$ & - & 0 \\
\hline Capreomycin (40 mg/liter) & - & 0 \\
\hline Isoniazid $(0.1 \mathrm{mg} /$ liter $)$ & + & 100 \\
\hline Isoniazid ( $1 \mathrm{mg} /$ liter $)$ & + & 80 \\
\hline Isoniazid ( $10 \mathrm{mg} /$ liter $)$ & - & 0 \\
\hline Rifampin ( $40 \mathrm{mg}$ /liter) & + & 80 \\
\hline p-Aminosalicylic acid $(0.5 \mathrm{mg} /$ liter $)$ & + & 100 \\
\hline Thiacetazone $(2 \mathrm{mg} /$ liter $)$ & + & 100 \\
\hline Thiacetazone ( $10 \mathrm{mg} /$ liter $)$ & + & 100 \\
\hline
\end{tabular}

TABLE 2. Levels of similarity between $M$. brumae CR-270 $\left(=\right.$ CIP $\left.103465^{T}\right)$ and type strains of 39 mycobacterial species and subspecies

\begin{tabular}{ll}
\hline \\
Species or subspecies
\end{tabular}

brumae revealed an absorption band at $965 \mathrm{~cm}^{-1}$ characteristic of trans double bonds, while absorption due to cyclopropane rings was not observed. The ${ }^{1} \mathrm{H}$ nuclear magnetic resonance spectrum confirmed this hypothesis by the presence of signals assignable to the resonance of olefinic protons at $\delta=5.35 \mathrm{ppm}$ and the absence of signals between $\delta=$ 0 and $\delta=0.7 \mathrm{ppm}$, corresponding to cyclopropane ring protons resonances. Argentation chromatography fractionated this mycolate spot into three main compounds; each class was subjected to oxidative cleavage, and the oxidation products were analyzed by gas chromatography. These analyses gave the composition shown in Fig. 4. The $I_{A}$ $\alpha$-mycolates were defined as diunsaturated esters with two trans double bonds, as suggested by infrared and ${ }^{1} \mathrm{H}$ nuclear magnetic resonance spectroscopy (multiplet of the double bond at $\delta=5.35 \mathrm{ppm}$ and additional methyl groups near the

\footnotetext{
${ }^{a}-$, negative reaction; + , positive reaction; $+^{w}$, weak reaction.

$b$ The values are the percentages of strains that are positive.

$c$ Weak reactions.
} 


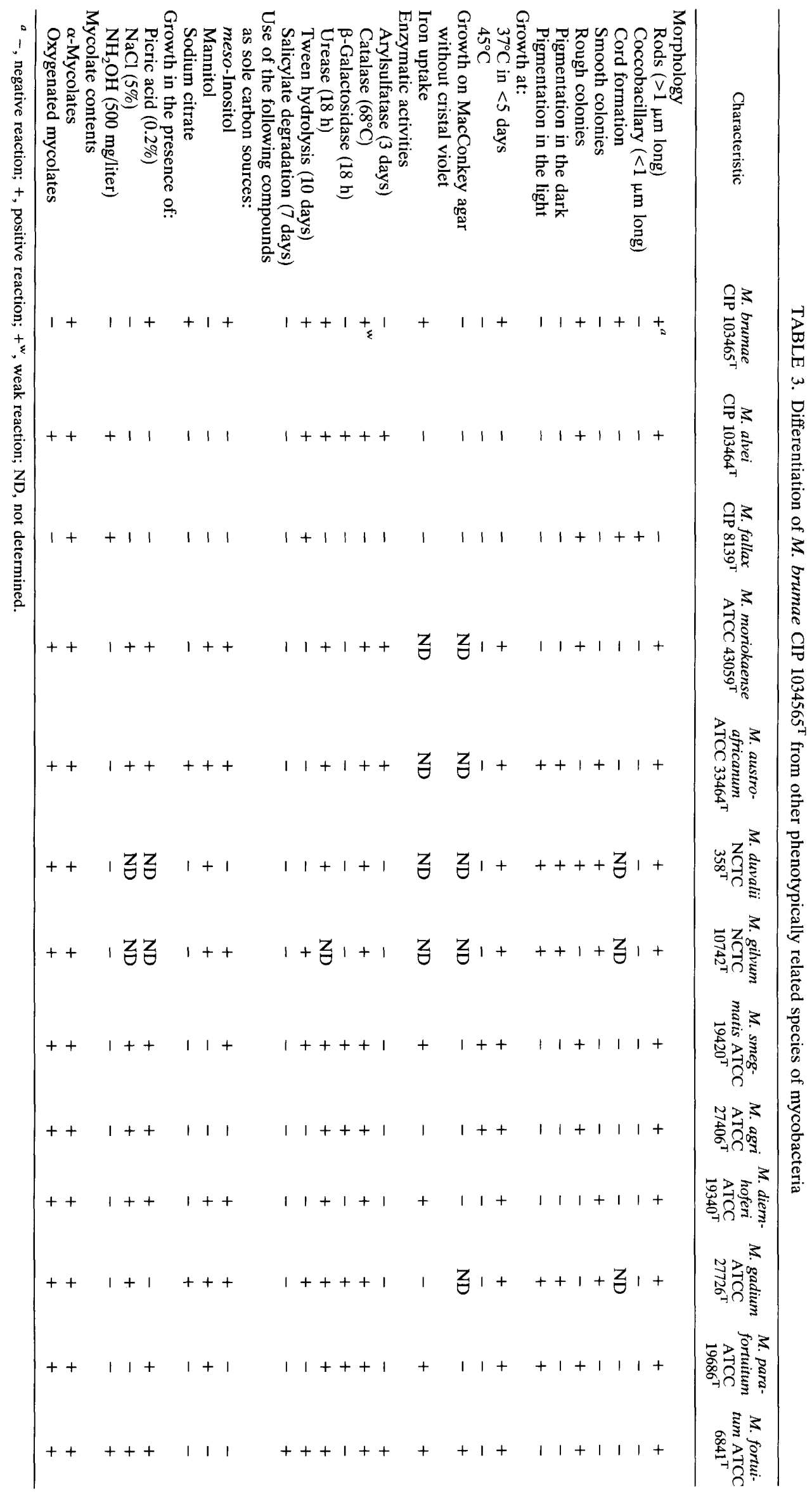



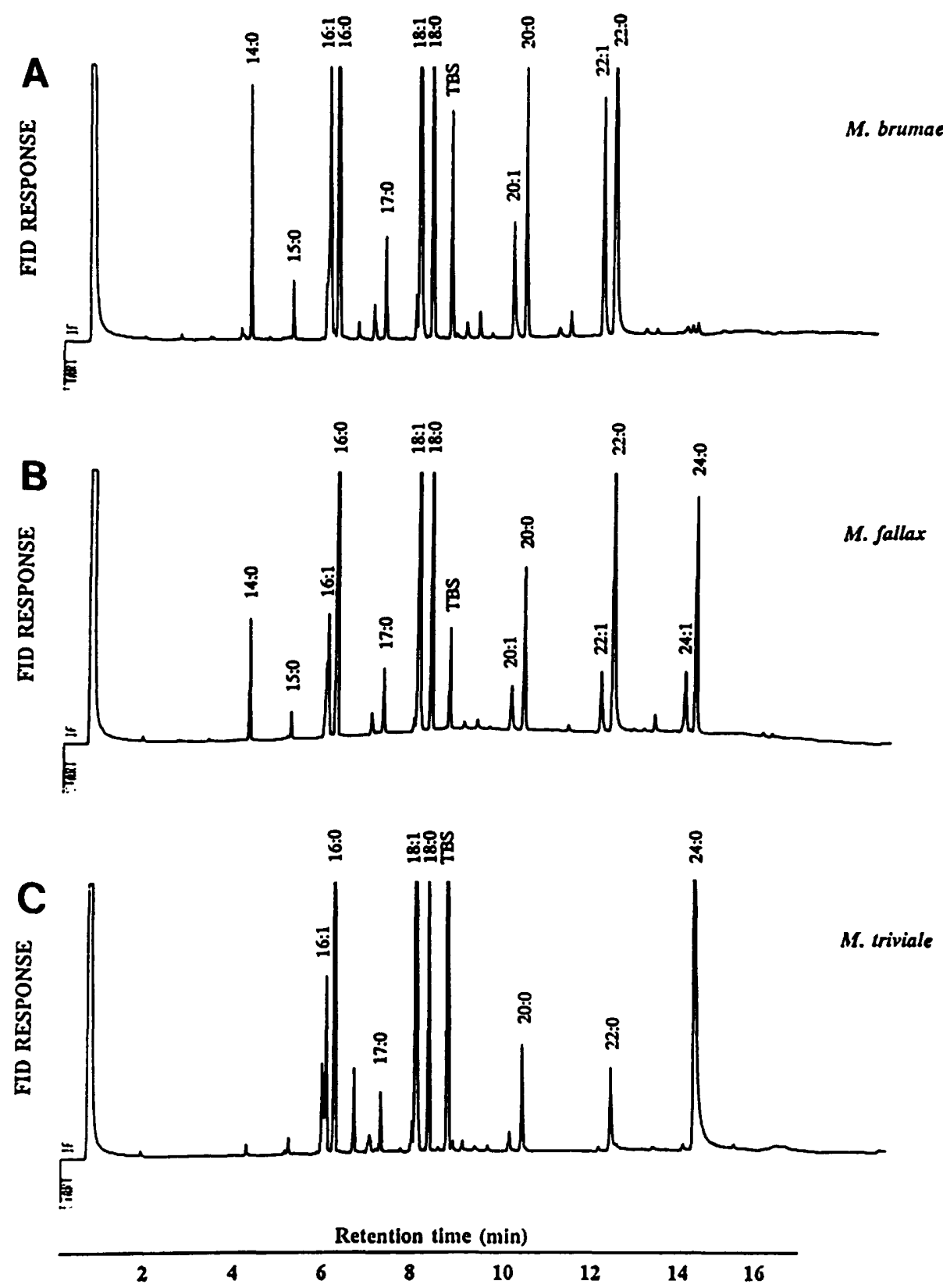

FIG. 2. Gas chromatogram of fatty acid methyl esters and mycolic acid cleavage products of $M$. brumae CIP $103465^{\mathrm{T}}$ (A), M. fallax CIPT $1390005^{\mathrm{T}}(\mathrm{B})$, and $M$. triviale ATCC $23292^{\mathrm{T}}(\mathrm{C})$. The numbers above the peaks indicate the number of carbon atoms, followed by the number of double bonds. TBS, tuberculostearate (10-methyloctadecanoate); FID, flame ionization detector.

double bond at $\delta=0.94 \mathrm{ppm}$ ) (13) and by the negative value of the molecular rotation of the intact mycolate (13). The main mycolic acid of this series contained 76 carbon atoms. The $\mathrm{I}_{\mathrm{B}} \alpha$-mycolates consisted of a mixture of compounds, each bearing one cis double bond and one trans double bond. The major mycolic acid of this series contained 75 carbon atoms. The $\mathrm{I}_{\mathrm{C}} \alpha$-mycolates contained only cis diunsaturated esters. ${ }^{1} \mathrm{H}$ nuclear magnetic resonance of this fraction showed a well-defined triplet at $\delta=5.35 \mathrm{ppm}$ (instead of a multiplet) assignable to the resonance of olefinic protons. These $\alpha$-mycolates consisted of mycolic acid homologs containing 68 to 76 carbon atoms (the main component was an acid with 70 carbon atoms). The chain length and the existence of double bonds in these mycolates indicate that they are related to $M$. fallax mycolates (22). However, the differences in the number of double bonds (tetraunsaturated $\alpha$-mycolates have been described in $M$. fallax) and in the chain length of the pyrolysis esters $(16,22)$ suggest that the new strains belong to a species different from $M$. fallax.

DNA relatedness. The ratios of absorbance for DNA solutions ranged from 1.9 to 2.1 and from 1.7 to 1.8 for the $A_{260} / A_{280}$ and $A_{260} / A_{230}$ ratios, respectively. The results of DNA-DNA hybridization experiments are shown in Table 4. We selected the type strains of species which produced the same mycolate pattern (only $\alpha$-mycolates) as $M$. brumae ( $M$. fallax and $M$. triviale) for DNA-DNA hybridization experi- 


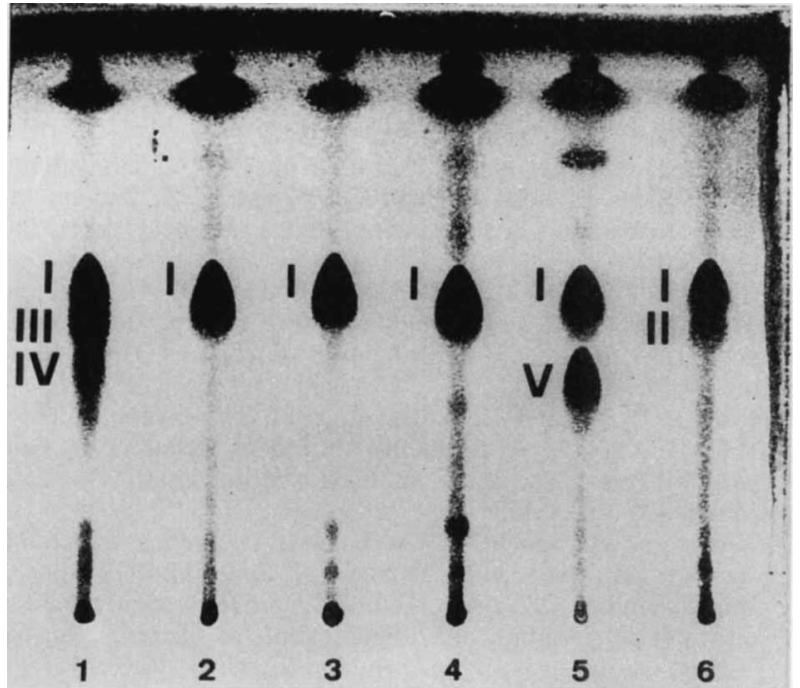

FIG. 3. Thin-layer chromatogram of methylmycolates from $M$. tuberculosis ATCC $27294^{\mathrm{T}}$ (lane 1), $M$. fallax CIPT $1390005^{\mathrm{T}}$ (lane 2), M. triviale ATCC $23292^{\mathrm{T}}$ (lane 3), M. brumae CIP $103465^{\mathrm{T}}$ (lane 4), $M$. fortuitum ATCC $6841^{\mathrm{T}}$ (lane 5), and $M$. chelonae NCTC $946^{\mathrm{T}}$ (lane 6). The mycolate types are indicated as follows: I, $\alpha$-mycolate; II, $\alpha^{\prime}$-mycolate; III, methoxymycolate, IV, ketomycolate; and V, epoxymycolate. The elution system consisted of two runs with petroleum ether-diethyl ether $(85: 15, \mathrm{vol} / \mathrm{vol})$ as the eluent.

ments, as well as other rapidly growing and slowly growing mycobacterial species. The use of the hybridization and S1 nuclease treatment conditions mentioned above resulted in levels of nonspecific hybridization (in control tubes containing herring DNA and labeled $M$. brumae CIP $103465^{\mathrm{T}}$ DNA) ranging from 7.6 to $9.4 \%$. Four strains of $M$. brumae were 95 to $100 \%$ related to strain CIP $103465^{\mathrm{T}}$, with $\Delta T_{m}$ values less than $2.5^{\circ} \mathrm{C}\left(\Delta T_{m}\right.$ is the difference between the $T_{m}$ of the homologous reaction and the $T_{m}$ of the heterologous reaction). The percentages of relative binding of strain CIP $103465^{\mathrm{T}}$ with all other strains were less than $30 \%$. The $\Delta T_{m}$ values determined for the higher levels of DNA complementarity were all more than $12.1^{\circ} \mathrm{C}$. The guanine-plus-cytosine $(\mathrm{G}+\mathrm{C})$ contents of DNAs were calculated from the melting temperatures by using the equation of Owen and Pitcher (21). The G+C content of strain CIP $103465^{\mathrm{T}}$ was $70 \mathrm{~mol} \%$. This value was an underestimation of the actual $\mathrm{G}+\mathrm{C}$ content as sonicated DNAs were used to determine the melting temperatures.

Description of type strain CR-270 (= CIP 103465) of Mycobacterium brumae sp. nov. Mycobacterium brumae (bru' mae. L. gen. n. brumae, of winter, referring to the time of year at which the first strains were isolated). The cells of $M$. brumae are gram-positive rods, 2.0 to $2.5 \mu \mathrm{m}$ long and 0.3 to $0.5 \mu \mathrm{m}$ wide; they are mostly strongly acid fast, except for a small number (less than 10\%) of cyanophil forms. Smears prepared from Youmans medium (without Tween 80) and Middlebrook 7H12 medium contain clumps or cords. Colonies on Löwenstein-Jensen medium and on Middlebrook $7 \mathrm{H10}$ agar are eugonic, rough, and nonpigmented in the dark or after exposure to light. Growth occurs within 5 days at 30 and $37^{\circ} \mathrm{C}$ but not at $45^{\circ} \mathrm{C}$. The type strain produces thermostable catalase and is positive for $\beta$-glucosidase, nitrate reductase, penicillinase, trehalase, urease, and iron uptake. Tween 80 is hydrolyzed after 10 days; niacin is not produced, and salicylate is not degraded to catechol. No growth occurs on MacConkey agar without crystal violet. Glucose, meso-inositol, fructose, and sodium citrate are utilized as sole carbon sources in the presence of ammoniacal nitrogen. Acid is produced from glucose, fructose, meso-inositol, and trehalose but not from L-arabinose, dulcitol, mannitol, Lrhamnose, and D-xylose. Growth is inhibited by sodium chloride $(5 \%)$, hydroxylamine $(500 \mathrm{mg} /$ liter $)$, D-cycloserine (30 mg/liter), ethambutol (2 mg/liter), kanamycin $(20 \mathrm{mg} /$ liter), capreomycin (40 mg/liter), and isoniazid (10 mg/liter).
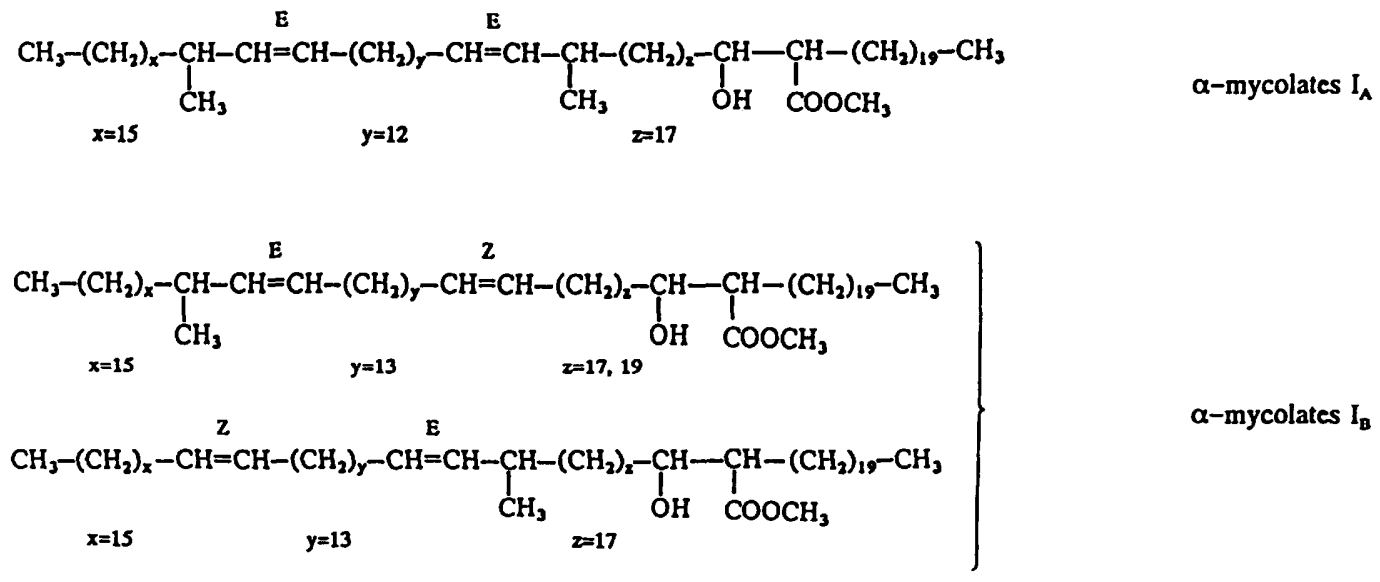

$\alpha$-mycolates $I_{B}$

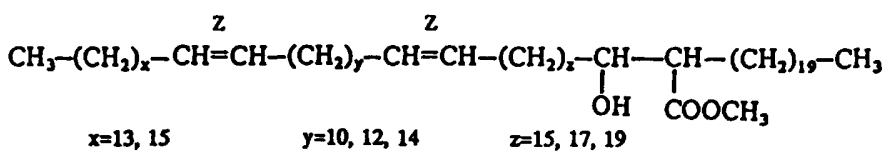

$\alpha-$ mycolates $I_{C}$

FIG. 4. Molecular structures of $\alpha$-mycolates of $M$. brumae CIP $103465^{\mathrm{T}}$. For double bonds, E indicates trans, and Z indicates cis. 
TABLE 4. Levels of DNA relatedness between strain CR $270^{\mathrm{T}}$ $\left(=\mathrm{CIP} 103465^{\mathrm{T}}\right)$ and reference strains belonging to selected mycobacterial species

\begin{tabular}{|c|c|c|c|}
\hline \multicolumn{3}{|c|}{ Source of $\mathrm{DNA}^{a}$} & \multirow{2}{*}{$\begin{array}{l}\text { \%o of relative } \\
\text { binding at } \\
75^{\circ} \mathrm{C}\end{array}$} \\
\hline Species & Strain & $\begin{array}{c}\text { Other } \\
\text { designation }\end{array}$ & \\
\hline \multirow[t]{5}{*}{ M. brumae } & $\begin{array}{l}\text { CR-270 } \\
\quad\left(=\text { CIP } 103465^{\mathrm{T}}\right)\end{array}$ & & 100 \\
\hline & CR-130 & & 100 \\
\hline & CR-267 & & 100 \\
\hline & CR-269 & & 100 \\
\hline & CR-142 & & 95 \\
\hline M. agri & CIPT $1320001^{\mathrm{T}}$ & ATCC $27406^{\mathrm{T}}$ & 20 \\
\hline M. alvei & CIP $103464^{\mathrm{T}}$ & & 7 \\
\hline \multirow[t]{2}{*}{ M. chelonae } & CIPT $0420003^{\mathrm{T}}$ & NCTC $946^{\mathrm{T}}$ & 7 \\
\hline & CIPT 801159 & & 4 \\
\hline M. chitae & CIPT $1160001^{\mathrm{T}}$ & ATCC $19627^{\mathrm{T}}$ & 12 \\
\hline \multirow[t]{3}{*}{ M. fallax } & CIPT $1390005^{\mathrm{T}}$ & CIP $8139^{\mathrm{T}}$ & 21 \\
\hline & CIPT 1390007 & & 24 \\
\hline & CIPT 1390014 & & 30 \\
\hline \multirow[t]{2}{*}{ M. fortuitum } & CIPT $0410001^{\mathrm{T}}$ & ATCC $6841^{\mathrm{T}}$ & 7 \\
\hline & CIPT 0410020 & ATCC 14467 & 11 \\
\hline M. gordonae & CIPT 0210008 & & 6 \\
\hline M. moriokaense & CIPT $1470001^{\mathrm{T}}$ & ATCC $43059^{\mathrm{T}}$ & 5 \\
\hline M. phlei & CIPT $1300001^{\mathrm{T}}$ & ATCC $11758^{\mathrm{T}}$ & 12 \\
\hline M. porcinum & CIPT $1460001^{\mathrm{T}}$ & ATCC $33776^{\mathrm{T}}$ & 10 \\
\hline M. pulveris & CIPT $1480001^{\mathrm{T}}$ & ATCC $35154^{\mathrm{T}}$ & 11 \\
\hline M. senegalense & CIPT $1350002^{\mathrm{T}}$ & NCTC $10956^{\mathrm{T}}$ & 12 \\
\hline M. smegmatis & CIPT $1330010^{\mathrm{T}}$ & ATCC $19420^{\mathrm{T}}$ & 14 \\
\hline M. triviale & CIPT $0330001^{T}$ & ATCC $23292^{\mathrm{T}}$ & 12 \\
\hline M. tuberculosis & CIPT 0010002 & ATCC 25177 & 21 \\
\hline
\end{tabular}

${ }^{a}$ CR, Collection of the Department of Tuberculosis, Hospital de la Santa Cruz y San Pablo, Barcelona, Spain; CIP, Collection Institut Pasteur, Paris, France; CIPT, Collection Institut Pasteur Tuberculose, Paris, France; ATCC, American Type Culture Collection, Rockville, Md.; NCTC, National Collection of Type Cultures, London, England.

Tuberculostearate is detected by gas chromatography; docosanoate is a mycolic acid cleavage product. Secondary alcohols are not detected. $M$. brumae contains only $\alpha$-mycolates (68 to 76 carbon atoms long), which release only docosanoate after pyrolysis.

\section{ACKNOWLEDGMENTS}

This work was supported by grant $91 / 0400$ from the Fondo de Investigaciones Sanitarias and by grant EE90/2-4.434 from the Comissió Interdepartamental de Recerca i Innovació Tecnológica.

We gratefully acknowledge E. Ageron and P. A. D. Grimont for their support in the carrying out of the DNA-DNA hybridizations and G. Loren for his assistance with the taxonomic study. We are also grateful to H. L. David for his helpful comments and suggestions throughout this study.

\section{REFERENCES}

1. Ausina, V., M. Luquin, M. García-Barceló, M. A. Lanéelle, V. Lévy-Frébault, F. Belda, and G. Prats. 1992. Mycobacterium alvei sp. nov. Int. J. Syst. Bacteriol. 42:529-535.

2. Canetti, G., N. Rist, and J. Grosset. 1963. Mesure de la sensibilité du bacille tuberculeux aux drogues antibacillaires par la méthode des proportions. Rev. Tuberc. Pneumol. 27:217-272.

3. Crosa, J. H., D. J. Brenner, and S. Falkow. 1973. Use of a single-strand-specific nuclease for analysis of bacterial and plasmid deoxyribonucleic acid homo- and heteroduplexes. J. Bacteriol. 115:904-911.

4. Dafié, M., M. A. Lanéelle, C. Asselineau, V. Lévy-Frébault, and H. David. 1983. Intérêt taxonomique des acides gras des mycobactéries: proposition d'une méthode d'analyse. Ann. Inst. Pasteur Microbiol. 134B:241-256.
5. David, H. L., and M. T. Jahan. 1977. $\beta$-Glucosidase activity in mycobacteria. J. Clin. Microbiol. 13:6-9.

6. David, H. L., I. Traore, and A. Feuillet. 1981. Differential identification of Mycobacterium fortuitum and Mycobacterium chelonei. J. Clin. Microbiol. 5:383-384.

7. Goodfellow, M. E., and D. E. Minnikin. 1984. Circumscription of the genus, p. 1-24. In G. P. Kubica and L. G. Wayne (ed.), The mycobacteria. A sourcebook. Part A. Marcel Dekker, Inc., New York.

8. Grimont, P. A. D., M. Y. Popoff, F. Grimont, C. Coynault, and M. Lemelin. 1980. Reproducibility and correlation study of three deoxyribonucleic acid hybridization procedures. Curr. Microbiol. 4:325-330.

9. Kubica, G. P., and H. L. David. 1980. The mycobacteria, p. 1693-1730. In A. C. Sonnenwirth and L. Jarett (ed.), Gradwohl's clinical laboratory methods and diagnosis. The C. V. Mosby Co., St. Louis.

10. Kubica, G. P., and R. C. Good. 1981. The genus Mycobacterium, p. 1962-1984. In M. P. Starr, H. Stolp, H. G. Trüper, A. Balows, and H. G. Schlegel (ed.), The prokaryotes: a handbook on habitats, isolation and identification of bacteria. Springer Verlag, Berlin.

11. Kubica, G. P., and G. L. Pool. 1960. Studies on the catalase activity of acid fast bacilli. I. An attempt to subgroup these organisms on the basis of their catalase activities at different temperatures and pH. Am. Rev. Respir. Dis. 81:387-391.

12. Lambert, M. A., C. W. Moss, V. A. Silcox, and R. C. Good. 1986. Analysis of mycolic acid cleavage products and cellular fatty acids of Mycobacterium species by capillary gas chromatography. J. Clin. Microbiol. 23:731-736.

13. Lanéelle, M. A., C. Lacave, M. Daffé, and G. Lanéelle. 1988. Mycolic acids of Mycobacterium aurum. Structure and biogenetic implications, Eur. J. Biochem. 177:631-635.

14. Lévy-Frébault, V., F. Grimont, P. A. D. Grimont, and H. L. David. 1984. Deoxyribonucleic acid relatedness study of Mycobacterium fallax. Int. J. Syst. Bacteriol. 34:423-425.

15. Lévy-Frébault, V., F. Grimont, P. A. D. Grimont, and H. L. David. 1986. Deoxyribonucleic acid relatedness study of the Mycobacterium fortuitum-Mycobacterium chelonae complex. Int. J. Syst. Bacteriol. 36:458-460.

16. Lévy-Frébault, V., J. Rafidinarivo, J. C. Promé, J. Grandry, H. Boisvert, and H. L. David. 1983. Mycobacterium fallax sp. nov. Int. J. Syst. Bacteriol. 33:333-346.

17. Luquin, M., V. Ausina, F. López-Calahorra, F. Belda, M. García-Barceló, C. Celma, and G. Prats. 1991. Evaluation of practical chromatografic procedures for identification of clinical isolates of mycobacteria. J. Clin. Microbiol. 29:120-130.

18. Luquin, M., J. Roussel, F. López-Calahorra, G. Lanéelle, V. Ausina, and M. A. Lanéelle. 1990. A novel mycolic acid in a Mycobacterium sp. from the environment. Eur. J. Biochem. 192: 753-759.

19. Minnikin, D. E., I. A. Hutchinson, A. B. Caldicott, and M. Goodfellow. 1980. Thin-layer chromatography of methanolysates of mycolic acid containing bacteria. J. Chromatogr. 188: 221-233.

20. Moore, W. E. C., and L. V. H. Moore. 1989. Index of the bacterial and yeast nomenclature changes, p. 41. American Society for Microbiology, Washington, D.C.

21. Owen, R. J., and D. Pitcher. 1985. Current methods for estimating DNA base composition and levels of DNA-DNA hybridization, p. 67-93. In M. Goodfellow and D. E. Minnikin (ed.), Chemical methods in bacterial systematics. Academic Press, Inc. (London), Ltd., London.

22. Rafidinarivo, E., J. C. Promé, and V. Lévy-Frébault. 1985. New kinds of unsaturated mycolic acids from Mycobacterium fallax sp. nov. Chem. Phys. Lipids 35:215-228.

23. Silcox, V. A., R. C. Good, and M. M. Floyd. 1981. Identification of clinically significant Mycobacterium fortuitum complex isolates. J. Clin. Microbiol. 14:686-691.

24. Skerman, V. B. D., V. McGowan, and P. H. A. Sneath (ed.). 1980. Approved lists of bacterial names. Int. J. Syst. Bacteriol. 30:225-420.

25. Sokal, R. R., and P. H. A. Sneath. 1963. Principles of numerical 
taxonomy. W. H. Freeman and Co., San Francisco.

26. Szabo, I., and E. Vandra. 1963. Mycobacterium minetti (Penso et. al., 1952): bacteriological and epidemiological observations. Acta Microbiol. Acad. Sci. Hung. 10:215-223.

27. Tsukamura, M. 1967. Identification of mycobacteria. Tubercle 48:311-338.

28. Vestal, A. 1975. Procedures for the isolation and identification of mycobacteria. Publication (CDC) 76-8230. Centers for Disease Control, Atlanta.

29. Wayne, L. G., H. C. Engbaek, H. W. B. Engel, S. Froman, W. Gross, J. Hawkins, W. Käppler, A. G. Karlson, H. H. Kleeberg, I. Krasnow, G. P. Kubica, C. McDurmont, E. E. Nel, S. R. Pattyn, K. H. Schröder, S. Showalter, I. Tarnok, M. Tsukamura, B. Vergmann, and E. Wolinsky. 1974. Highly reproducible techniques for use in systematic bacteriology in the genus Mycobacterium: tests for pigment, urease, resistance to sodium chloride, hydrolysis of Tween 80 , and $\beta$-galactosidase. Int. J. Syst. Bacteriol. 24:412-419.

30. Wayne, L. G., H. W. B. Engel, C. Grassi, W. Gross, J. Hawkins, P. A. Jenkins, W. Käppler, H. H. Kleeberg, I. Krasnow, E. E. Nel, S. R. Pattyn, P. A. Richards, S. Showalter, M. Slosarek, I. Szabo, I. Tarnok, M. Tsukamura, B. Vergmann, and E. Wolinsky. 1976. Highly reproducible techniques for use in systematic bacteriology in the genus Mycobacterium: tests for niacin and catalase and for resistance to isoniazid, thiophene-2-carboxylic acid hydrazide, hydroxylamine, and $p$-nitrobenzoate. Int. J. Syst. Bacteriol. 26:311-318. 